\title{
Geopolitical Bodies: Media Discourse on the Indonesian National Identity
}

\author{
MUHAMMAD RIDHLO AL QODRI SRI UTOMO \\ IAIN Tulungagung, Indonesia
}

\begin{abstract}
The paper examines how Indonesian media contested for the Indonesian national identity, from the period of National Awakening (1908) to the period of Sukarno's Guided Democracy (1957-1965), focusing on the issue of human body constructions. The paper is based on qualitative discourse analysis, applying Norman Fairclough's discourse method, especially the analysis of discourse practices and social changes. The data were collected from several media, such as books, newspapers, and advertisements in the periods being studied. The study finds that the national identity contestations involved the struggle to construct and discipline the human body, which was influenced by traditional Javanese culture, Dutch imperialism, Japanese occupation, and national independence spirits. In the Javanese culture, the body is perceived as a sacred site, while the Dutch colonialism has transformed this idea of sacred and collective bodies to the more secular and individualized bodies. The Japanese occupation has totally mobilized the human body into a collective single identity. After independence, the human body discourse was closely related to the geopolitical tensions between nationalist (Javanese) and modernist (non-Javanese) discourses. The nationalist suggested that Indonesia needs to form a collective physical identity for nation-building, while the modernist suggested accommodating cosmopolitanism and individualism to build a national identity. The contestations for Indonesian national identity were not complete until 1965, which has also triggered the crisis of national unity in the middle of the 1960s. The study also concludes that the discourse of the human body was very important in the debate of Indonesian national identity.
\end{abstract}

Keywords: Human body, geopolitical body, discourse analysis, media contestation, Indonesian national identity.

\section{INTRODUCTION}

Until 1965, the human body was seen as the contested field for Indonesian national identity. In order to project Nation and Character Building (Tim Penyusun, 1964), Sukarno (Indonesia first president, 1945-1967) rejected the bouffant hairstyle and then instructed the Police to hold Indonesian youth who imitate this British musician mode (Soekarno, 1964; McIntyre, 2005). Two years earlier, the book entitled Tata Krama Nasional Indonesia: Etiquette (Indonesian national etiquette) (Oetomo, 1963) which has published with the support of the local government of Yogyakarta, has outlined the national bodily manners, including how to sleep, bathe, walk, and sit.

In the earlier of the 20th century, the idea of Indonesia developed and gradually involved the question about what the identity of a nation was. Thereafter, the national identity was searched through national education, such as conducted by Budi Utomo (1908), through politics, such as Partai Nasionalis Indonesia (PNI) - Indonesian Nationalist Party (1927), also through language and territories, such as reflected in Sumpah Pemuda - Youth Pledge (1928).

The great contribution to the earlier building of national identity was Budi Utomo. It was founded in 1908, which further memorized as the period of Indonesian national awakening. The members of this organization were not only Javanese but also Sumatran (Kurasawa, 1989). One of its leaders was Ki Hadjar Dewantara, who was also the founder of a 
native school called Taman Siswa. For long years before and after Indonesian independence, Dewantara has suggested several ideas of national education. He was argued as the earlier pribumi who has developed the Indonesian education system.

Additionally, in 1928, Indonesian national identity was fundamentally signified with the unity of language (bahasa), nation (bangsa), and motherland (tanah air) (Ricklefs, 2001). This idea was declared in Sumpah Pemuda (Youth Pledge), which has involved not only a number of youths from various regions in Indonesia (Java, Sumatra, and Sulawesi), but also from Indo-Chinese youth, such as Sie Kong Liong and Kwee Thiam Hong. In fact, Sie Kong Liong's house was the place of this youth congress. Besides searching the territorial visions for nationalism, the congress was organized as the collective reactions to the colonialism that occurred in the Indonesian regions.

The study of the human body in the history of Indonesian national identity is very rare. While polemic about Indonesian national identity in the early days of independence has debated a lot of aspects, but not human body, such as ideology (Aidit, 2007), influence of foreign culture (Hatta, 2007), cultural imperialism (Suryadarma, 2007), and traditional culture (Slamet, 2007). In addition, previous studies related to the human body have concerned the bodily representations, such as clothing and gender (Taylor, 1997) or clothing and political identity (Mrazek, 1997).

This paper examines how Indonesian media discourse for a national identity, focusing on their discursive practices on the Indonesian human body. I would argue that the discourse of the human body is closely related to the geopolitical friction between nationalist (Javanese) and modernist (non-Javanese), which has happened in many periods of modern Indonesian history. The realms also spark a question of why the body was very important in the debate of national identity.

\section{METHODOLOGY}

This article is based on qualitative research applying discourse analysis as proposed by Norman Fairclough, especially in his book entitled 'Discourse and Social Change' (1993). Norman Fairclough articulated discourse as a system of ideas or thought, which is represented through texts, images, or various forms of symbolic languages (Fairclough, 1993). A discourse arises and emerges in a certain period, and then it can change, break, or contradict each other. In this notion, the role of discourse analysis is to explicate and clarify discursive formations in a specific period, the dominant ideas in the specific era, or the main argumentations connecting people at a certain historical time.

There are three analytical steps according to Fairclough, namely data, analysis, and results (Fairclough, 1993). Data consists of defining the project, determining corpus, increasing corpus, selecting examples, doing transcription, coding and selecting samples in the corpus. While at the level of analysis, researcher links the data into the aspects of discourse practices (interdiscursive, intertextuality) and texts (interactional control, cohesion, politeness, grammar, transitivity, themes, modalities, word meanings, metaphors, discourse sequences, ideological and political effects of discourse). Finally, results consist of discursive traces that have implications to the socio-cultural orders.

The data was collected from several media, such as books, newspapers, photos, and advertisements, from the period of 1900 to 1965. Fairclough (1993) has suggested that discourse analysis has to carefully take into account the social changes determined by the relationships between power structures and socio-cultural systems in society. In the context of this study, the data were differentiated based on the power structures in the period of 
1900-1965, consisting of the Dutch colonial period (1990-1942), the Japanese occupation (1942-1945), and the independence period (1945-1965). This historical separation is very important to understand the dynamics of the power structure and its implications for human body construction.

\section{The Sacred Javanese Body}

\section{RESULT AND DISCUSSION}

During his command as the British Lieutenant-Governor of the Java Island (1811-1816), Raffles noted there was much uncut hair on Javanese people, which was oiled by Cendana and Gandapura (Raffles, 2008). While their skin was covered with traditional powder, their long hair commonly looped around the neck. Javanese women commonly washed their long hair with flowers that soaked in water for daily rites, also washed with rice straw (merang) for slametan rites, such as mitoni (seven months pregnant), married, and first menstruation. A straw is not only believed for strengthening the hair roots but also believed to have the supernatural power of prosperity. Meanwhile, Koentjaraningrat explained these traditional ceremonies as "ritus kritis" (critical rites), refer to all efforts to prepare human physic and spirit in the transitional processes within nature (Koentjaraningrat, 1993).

Thereafter, Dutch bodily manners contributed to Javanese society since the nineteenth century, and the Javanese bodily rites gradually reduced. In that period, the arrival of Islam and Western Christianity have transferred the traditional view about uncut hair to cut hair. Additionally, the use of forks and spoons that were introduced in Dutch education, had marginalized the Javanese concept of eating by hand (Keizer, 1916), which was previously connoted with the Javanese religion (Lombard, 2008).

\section{Individualized Body During the Dutch Colonization}

During the 18th century, the body was the main site of 'the civilizing processes' (Atkinson, 2000) of the colony with European manners. During this period, civilizing processes were started from the hygiene behavior of the European court society and then gradually disseminated to the colonized people. These civilized bodies have then influenced historical transformation in behavioral codes and forms of the colonized nations (Shilling, 2003).

Cholera (1821) and Dipanegara's War (1825-1830) have increased the number of mortalities in Java. It has driven the Dutch to campaign health care, especially for the workers in the cultivation system. Since the 1850s, public health care has emphasized physical hygiene, cleanliness, and modern bathing (Taylor, 2011). Since the Ethical Policy (1901), Dutch has spread the knowledge about body illness (Ooms, 1927), skins care (Joesoef, 1917), scabies preventions (Schurft, 1919), also diseases and hygiene manners (Keizer, 1916).

The knowledge of disease-preventing in early modern society, as Bryan Turner has argued, has transposed the traditional bodies, which previously featured by sacred articulations, to a more secular and modern perspective (Turner, 2007). Moreover, it could be argued that secularized bodies have also transferred the collective bodies with more individualized manners, in which every people has the choice to perceive their body as an independent self, apart from another body (Shilling, 2003). Previously, the collective manners of traditional society always treat individuals as a part of society, regulated by customs, laws, and wisdom. In this perspective, personal choices are very limited, even not allowed in certain fundamental features. Then, the new ideas of the human body introduced by the Dutch have challenged these collective manners with individualized perspectives. 
As a result, the Dutch-educated Indonesian people not only understood the sacral conceptions of the body, but also the secular individual ideas of the body. Even, many Prijaji has left the old sacral body, and moved to the secular ideas. Accordingly, Aria Achmad Djajanidiningrat (1877-1943) told how he has separated from his older family because of the shaking hands and sitting on the chair as the manners taught in the Dutch primary school. These manners have made him westernized and separated from his society (Zinoman, 2014). This story shows how Dutch educated Indonesians were not only affected by modern orientations but also separated from their society.

During the 1920s, western civilized bodies were discussed in several newspapers. In 1920, Soeloeh Indonesia (Surabaya, Java) reported that western culture pressured Indonesian women through shortening hairstyle (Redaksi, 1926). In contrast, in Pertja Timoer newspaper (Picture 1), Siti Baserah wrote about a short hairstyle as the demands of the modern time. She suggested shortening the hair as a personal choice, "kesoekaan diri sendiri" (contentment of the self) (Baserah, 1929). In addition, many opinions have suggested individual bodily orientations, for example, the psychological body management (Istidjab, 1931). While, children were taught with individual etiquettes, such as brushing teeth and cleaning of the body in everyday life (Soegiarti, 1936).

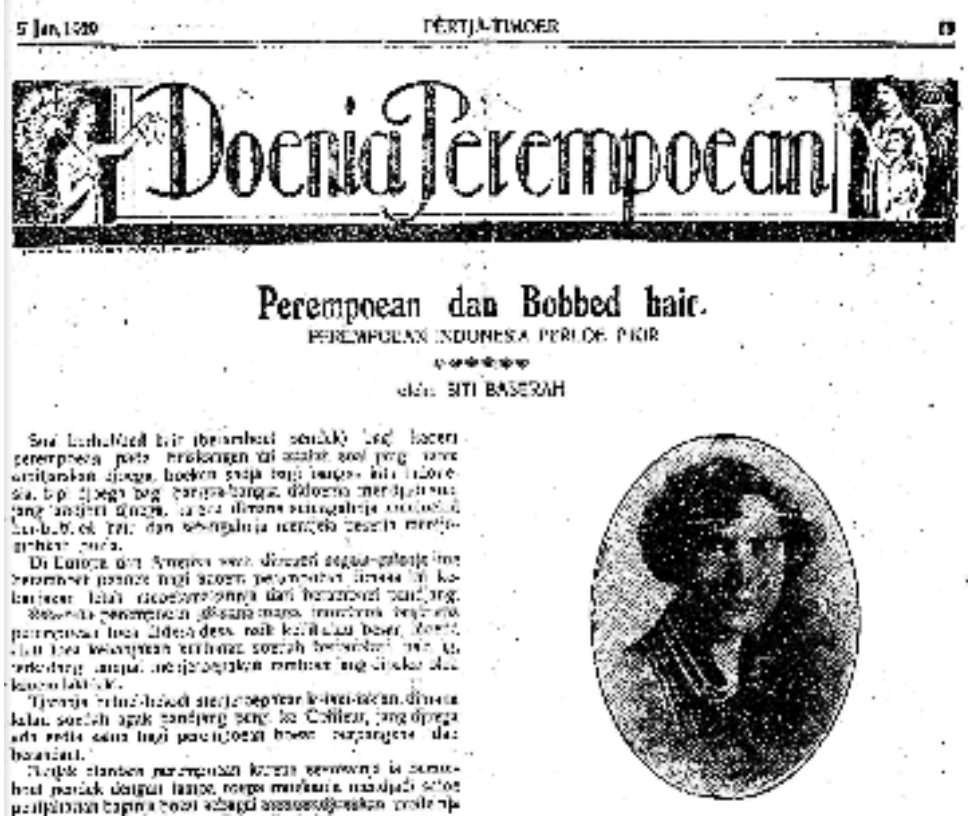

Picture 1: Article about short hairstyle in Pertja Timoer newspaper, Medan (1929)

In this era, the products of bodily health care and their advertisements have represented the secular body images. There were many advertisements offering shampoo, hairdryer, soap, and skin medicine. Ramboet Netjis ads (in Bahagia, 1929), persuaded people to use a product which can manipulate gray hair to black hair (Picture 2). Additionally, in Obat Kramas tjap Dewa ads (Picture 3), the hair care product claimed that it was able to clean the head skin and make a fresh brain (in Pemandangan, 1938). Most of the advertisements have not represented anymore the traditional ideas of sacred bodies, otherwise, they have portrayed pleasure and enjoyment of modern bodies. 


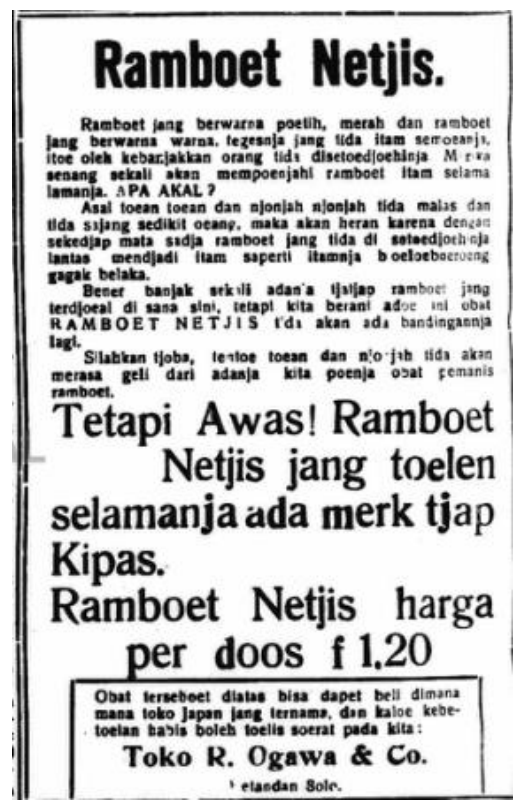

Picture 2: Advertisement in Bahagia, 1 May 1929

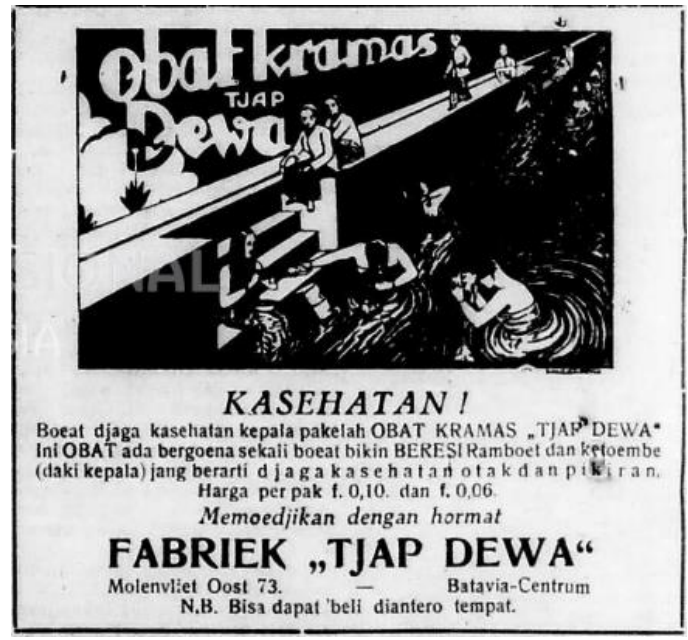

Picture 3: Advertisement in Pemandangan, 12 February 1938

As a result, the idea of the Indonesian body has been transformed from the collective and sacred orientations of the traditional body to the new secular and individualized body. Moreover, the publications in the first half of the 20th century have not only introduced new knowledge about hygiene manners and body health care for Indonesian people but have also exposed the substantial ideas of the individualized embodiment and secular ways of existing in the modern world.

\section{Mobilized Body Under the Japanese Occupation}

Civilizing body processes during the Dutch colonization have been broken down by the Japanese occupation (1942-1945), especially through Japanese military training (kyôren), moral education (shûshin), and physical training (taishô) (Kurasawa, 1989). Rudolf Mrazek called it 'the Japanese politics of manners' (Mrazek, 2002). Taishô in Japanese term means 'body exercises'. As Shimizu Satoshi has traced, it refers to the code of conduct of soldiers, 
including disciplining of the body, routinely doing military drills, intensifying of the health, practicing hygiene body, and fully respecting the ruler-order (Satoshi, 2007).

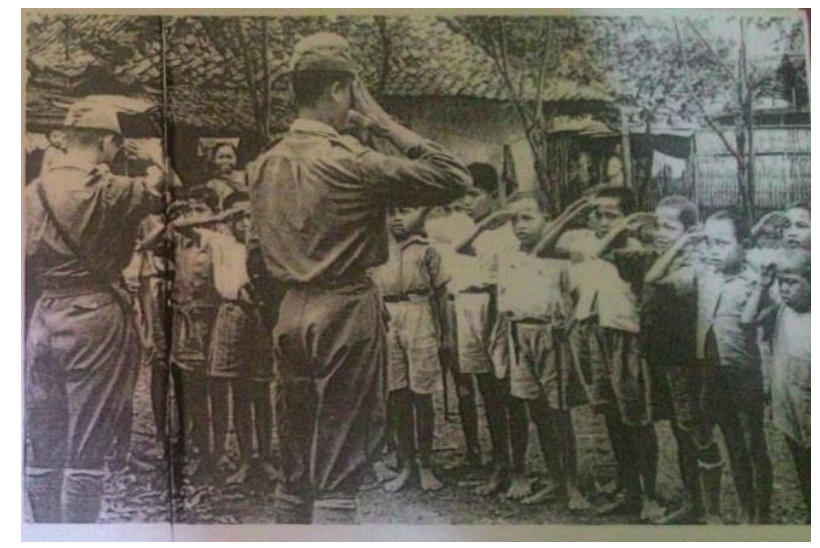

Picture 4: Japanese military training for Javanese children (Djawa Baroe)

Aiko Kurasawa has described the education curriculum during the Japanese occupation in Indonesia, in which "physical training was also made much of and both military training and gymnastics were introduced" (Kurasawa, 2015). Every morning, accompanied by radio taisho who broadcasted certain fast rhythmic music, Indonesian people might wear the same uniform and perform the series of body movements collectively. It was also followed by singing Japanese education and military songs. Suparta Brata has noted in his last memorable novel about Japanese occupations in Surabaya. He wrote about "radio taisho" and the other Japanese manners in the classroom. After the taisho, the student practiced a set of Japanese behavior and gestures, such as stand at attention in the classroom, head bowed before and after speaking, and certain seated attitude before entering and leaving the classroom. This propaganda was also operated in Malay and Singapore during the Japanese occupation (Akashi, 1993).

In addition, the Japanese occupation in Southeast Asia has proclaimed Pan-Asianism ideology. The notion of 'Asia' consists of racial and cultural bodies. It could create a boundary with the Western and Europe and persuade singularities and unity of culture and religion within Southeast Asia (Hotta, 2007). It was also practiced in education agendas. Then, it was supported by several Indonesian intellectuals, especially Javanese, who have argued to resist against the western civilization, such as Ki Hajar Dewantara, Mangoensarkoro and Djatikoesoemo. Ki Hajar Dewantara has written several articles that rejected individualization in Dutch manners education, otherwise suggested social responsibility of Indonesian manners (Dewantara, 1962). Mangoensarkoro, following Dewantara, has also differentiated 'individual education' (pendidikan perseorangan) in the Dutch colonial era with 'social education' (pendidikan kemasjarakatan) in the Japanese era (Mangoensarkoro, 1943). He suggested that education should emphasize the inner aspects of collectivity, including sacrifice, generosity, and tolerance. Besides, Sosodoro Djatikoesoemo has shown the importance of Japanese propaganda to build Indonesian culture through the manners of east-nations (Djatikoesomoe, 1944).

Furthermore, the Japanese mass education has affected the sense of Indonesian collectivism which was ordered by total mobilization. It was also applied to the human body, which was organized through long march, military training, sumo exercises, meditations, sport, health care, taisho, and dress uniformity. It enacted collectivism for children, adults, 
women, and men. The most important meaning of this program was to reunite the whole parts of society in one order and control. Through body exercises in the mobilization propaganda, Japanese occupation in Indonesia has persuaded to accept collectivism of eastern nations' civilization and to reject western individualism. These mobilizations, in fact, would supply the Indonesian leadership after Independence (Ken'ichi, 2007).

\section{Contested Body in the Independence Era}

After national independence (1945), Indonesians had more different articulations of the human body. The varieties of cultural embodiment not only referred to the physical behaviors, but also related to the geopolitical circumstances. The contestation showed that there were large tensions between nationalist (Javanese) and modernist (non-Javanese) bodily views.

On the one side, the national body was most represented by Javanese opinions. The traditional views about the Javanese body still appeared in several publications. In the 1950s, Madjalah Rakjat suggested the traditional Javanese body maintenance, such as washing the hair with merang and brushing the teeth with betel leaf stalk (Tim Penyusun, 1951). In order to build national unity which is not affected by Western culture, nationalist claimed that Indonesia needs to form the physical identity for nation-building. During the 1950s, Ibu Dwidjo, a Javanese-nationalist, has criticized Western hairstyle and modern clothing (Dwidjo, 1952a). Most of her articles have been published in Nasional weekly magazine. In an article, she argued about the woman who has a short hairstyle like a woman who has no right brain (Dwidjo, 1952b). Otherwise, she supported Indonesian education should consist of bodily manners which are inspired by Pancasila (Dwidjo, 1952c).

In that period, the nationalist argued that collective ways were needed in order to form the nation-state building of Indonesia. After independence, Indonesian society seemed to be more attached to the ideas of integration, cohesion, solidarity, and collectivity (Feith, 2007). Individualism had been articulated with negative meanings. In contrast, collectivism, communalism, socialism, national identity, had positive articulations.

In 1955, Harian Rakjat newspaper, a publication of Partai Komunis Indonesia (Indonesian Communist Party), reported the movement to criticize the sleeveless dress and jeans as demoralization of the youth (Wiedija, 1955). It was the year of the movement of the anti-sleeveless dress (Redaksi, 1955). The main argument of these publications intentionally confronted to the Indonesian who supported Western dress and its erotic bodily appearances. Furthermore, in 1960, Api Kartini, Gerwani's magazine under PKI, rejected the bodily orientations of the Western corset for streamlining the waist (Redaksi, 1960).

The Japanese discourses on education, body exercises, and bodily manners have strongly influenced the sense of unity of Indonesian people. Since the 1950s, the Japanese mobilization models have been partly adopted in order to build Indonesian national identity. It happened gradually since Sukarno projected his agendas for nation building in 1957 (Soekarno, 1986), guided democracy (Soekarno, 1959), nation and character building in 1963 (Manipol-USDEK) (Abdugani, 1963), and then more explicitly in "tahun berdikari" (selfsustained year) (Departemen Penerangan RI, 1965).

Since proclaimed guided democracy, Sukarno told about kepribadian bangsa (nation character) in Manipol-USDEK and instructed to establish Lembaga Pembinaan Kesatuan Bangsa (LPKB) - (Institution of National Unity Building) in July 1963. In 1964, Roeslan Abdulgani, who led this institution, published Pembinaan Kesatuan Bangsa (National Unity 
Building), which has stressed to bring up the unity, equal character, and the totality of nation (Abdulgani, 1964). Additionally, LPKB also published Pembinaan Mental dan Kesatuan Bangsa (National Unity and Character Building) (Tim Penyusun, 1964). It was also added with a publication of the guideline book, wrote by Oetomo Ds (1963), titled Tata Krama Nasional Indonesia: Etiquette (Indonesian National Etiquette). The book was supported by Departemen Pendidikan dan Kebudayaan (the Department of Culture and Education). It has outlined everyday manners, such as how the way of sleeping, bathing, walking and sitting. In the introduction, the book mentioned that it was intended as a values embodiment as the mandate of President Sukarno, the fostering of a nation through his own determination of manners system, which applied to all citizens, in order to realize the personality of the nationidentity.

In the end years of the Sukarno era, the body and its manners have become a more important field for shaping the national identity. In 1964, Sukarno rejected a bouffant hairstyle (Soekarno, 1964). He has also instructed the Police to hold the Indonesian youth who imitate the bouffant hair of British pop music (Mclntyre, 2005). The bouffant hairstyle was considered as a form of cultural capitalism and not in the line of the political setup of Sukarno. Then, Sukarno proclaimed the political manifesto prohibiting other forms of Western culture which is mostly represented through pop music and lifestyles.

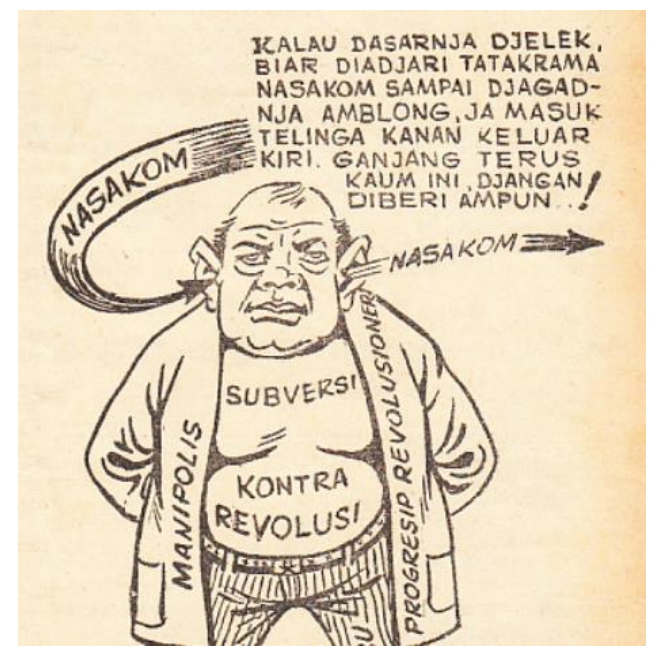

Picture 5: western body image in Minggu Pagi newspaper

After Sukarno formed Lembaga Pembinaan Kesatuan Bangsa (LPKB) in 1963, the antimodernist body has widespread in the larger social movements. In 1964, The Movement of Yogyakarta's Women Organization (Gerakan Organisasi Wanita Yogyakarta) rejected Western hairstyles and skirt (Redaksi, 1964). Moreover, in the same year, in order to support Sukarno's political manifesto, Minggu Pagi newspaper, based in Yogyakarta, campaigned to reject Western bodily eroticism (Pramono, 1964). There were several other supports to Sukarno's political agenda, such as campaigns against free sex to support the Manipol (Pramono, 1964). Another example, disabled people supported guided democracy and tata krama Nasakom (Nasakom manners) to resist against Western civilization (Redaksi, 1965).

On the other side, modern orientations of the bodies were mostly suggested by nonJavanese writers. They were more interested in western culture and cosmopolitanism rather than traditional culture. During 1947-1952, Star Weekly, the Indo-Chinese newspaper, has promoted various modern body ideas. For example, they wrote about the importance of 
cream to prevent skin from wrinkles (McCormick, 1947) and the increase of modern culture in dress and hairstyle (Hauw, 1949). The modern dance for Indo-Chinese youth was also supported to differentiate them from the older generations (Redaksi, 1947).

Additionally, in 1962, Keluarga magazine promoted the style of sleeveless dress (Redaksi, 1962). This article seemed to directly contrast Bu Dwidjo's opinion as nationalist in two years earlier who has worried about the youth fashioning in the sleeveless dress. Furthermore, the magazine appointed the modern way of body beautification with skin lotions (Kumaratih, 1962), style of the skirt (Redaksi, 1965), hairstyles (Kumaratih, 1962), exercises to maintain a slim body (Redaksi 1961), and another modern body maintenance, such as how to take care of chest, legs, and waist (Kumaratih, 1960). Thus, in general, modern perspectives have tried to accommodate cosmopolitanism, modernism, and individualism to build the Indonesian body as a national identity.

In fact, Keluarga magazine was published by Herawati Diah (born at Belitung, Sumatra) since 1953, who was B.M. Diah's wife (born at Aceh, Sumatra). Interestingly, in the 1960s, B.M. Diah, who was also the founder of Merdeka newspaper, involved in Badan Pendukung Soekarnoisme (BPS) - the Support Agency of Soekarnoism, an anti-communist organization for criticizing PKI's domination in the Sukarno's presidential periods (Kumpulan Berita, 1965).

\section{Geopolitical Circumstances}

The most important question in those historical circumstances is why the human body became crucial in the contestation of Indonesian national identity. I would argue that there are two main factors influencing these human body contestations. The first factor is related to the debate around the orientations of Indonesian national identity which is divided into pro-western and pro-national identity (Feith \& Castles, 2007). The second factor is the friction in the national political arena, between Javanese and non-Javanese leaders, especially Sumatrans.

It was very important for PNI and PKI, whose members were majority Javanese abangan who less modern-educated (Ricklefs, 2001), to attract the native sympathy through anti-western propaganda. The native directly felt the pains during the Dutch and Japanese occupations, rather than priyayi (aristocrat, feudal society) who were more western-educated and had social opportunities during the colonization era. Even after Sukarno buried the parties and formed Dewan Nasional (the National Council), which has involved various commoners in the parliament, rather than politicians from political parties. Sukarno has tried to transfer political power into the hands of the commoners (Ricklefs, 2001). At the moment, the political setting has forced the political parties to make impressive propaganda through the issue of national identity for the lower-class society, rather than proposed the westernoriented ideas.

Previously, as a feudal society, the Javanese court ruled their commoners to respect them with bodily gestures, called sembah. It was generally perceived that the goddess was immanent in the body of the King, and the common people (rakyat) should give their bodily gesture of sembah, which means as their recognition of the court nobility as sacred peoples. During their occupation, the Dutch banned pribumi not to practice this hierarchical body language (Buhger, 1983). However, the sembah has transformed into hormat gesture for military purposes when the Japanese ruled Indonesia. 
The Dutch new modern manners have not only separated between the sacred and the modern body, between the collective and the individual body but have also decreased the Javanese aristocrat authority. This decrease then continued after independence. The native aristocrat lost their authorities and social honors when their power was diminished due to the social structures change after the formation of nation-state. Moreover, in 1961, Sukarno condemned "'Ladies Movement' Ndoro Den Ayu" (Soekarno, 1961). He persuaded Indonesian people to transform the Javanese court culture (budaya Kraton) to the commoner culture (budaya rakjat). But, paradoxically, Sukarno seemed that he also wanted to be respected by Indonesian people with hormat gesture. He has transformed Javanese sembah with a more secular gesture of hormat, though it was adopted from Japanese military drills.

Interestingly, while on the one hand, this transformation has decreased the social status of the feudal society, on the other hand, it has increased the intellectuals with new high social status (Soekarno, 1961). But, as most of the native intellectuals were actually also members of the feudal society, they were consequently separated from their own society. The Javanese nobilities, who had the privilege in Dutch education like Aria Ahmad Djajadiningrat, as mentioned beforehand, were separated from their older culture and generations.

The second factor was the friction between the modernist and nationalist ideas, which could be related to the conflict between Javanese and non-Javanese leaders, especially Sumatrans, in the political arena, although not all. It was the friction between two main political orientations during 1950-1965, that can be divided into two different geopolitical orientations, namely the outer islands of Java, especially Sumatra, as socialist-democratmodernist, and Javanese as nationalist-orthodox-communist (Ricklefs, 2001).

In 1958, many Sumatran leaders, including Muhammad Natsir (Masyumi), led the rebels of the Revolutionary Government of the Indonesian Republic (Pemerintahan Revolusioner Republik Indonesia, PRRI) (Ricklefs, 2001). Natsir has known as a modernist who accepted western influence rather than traditional culture. In addition, Mohammad Hatta also knew as a socialist democrat who accepted modern western ideas. Hatta, Natsir, also Sjahrir, were Sumatran. Sukarno reacted to PRRI's rebels. This PRRI movement, as Sukarno has claimed, was a Sumatran mobilization of anti-Jakarta, the Indonesian capital located in West Java (Soekarno, 1986). He accused Sumatran leaders had demanded a bigger share of state revenues into Sumatra (Adams, 1966). He also claimed that the rebels had been influenced by foreign military powers around Southeast Asia (Soekarno, 1963). Sukarno was worried about the movements of non-Javanese power. Moreover, previously in 1956, Sumatran army officers of Banteng Divisions (Dewan Banteng) had demanded the autonomy of Sumatra regions from Jakarta (Ricklefs, 2001). In the 1960s, Natsir was condemned as he had confronted with Sukarno's Political Manifesto (Redaksi, 1964).

\section{The Crisis of National Unity}

The friction between Javanese and non-Javanese national leaders has created social antagonism and distrust. This was coexistence with the geopolitical conditions of the era.

The formation of Lembaga Pembinaan Kesatuan Bangsa in 1963, which has stressed to unify the Indonesians body, was affected by Sukarno's geopolitical motive of the nation as reflected in his argumentation of Pancasila's third line, 'the unity of Indonesia' (Persatuan Indonesia). This geopolitics idea covered all islands around the archipelago as Indonesian identity and motherland, assuming the uniformity of emotional sentiments of the people around the archipelago (Soekarno, 1968; Soekarno, 1958). 
Inconsistency acts toward Pancasila as the national identity, which was ironically founded by Sukarno in 1945, has significant impacts on the nation-state building. The most critical problem was how Sukarno argued about national identity which is not only constituted through geographical scopes but also material elements (Soekarno, 1963). The national body seems to be projected by the notion of material embodiments that related to the geographical motive. Sukarno and his political affiliations (PNI, PKI, and NU) have pushed the national body to all attempts in order to rise territorial dignity around Malays archipelago, also to the struggle for liberating the West Papua into Indonesia's regions (Soekarno, 1962).

Sukarno has partly adopted the Japanese mobilization to build the Indonesian national body. In fact, there was a number of similarities between Japanese propaganda and Sukarno's mobilizing bodies, for example, hand gesture (hormat) signifies the unity (persatuan), rejects the differences, also refused against western individualized bodies. Thus, although Sukarno intended the unity for national stability, he has also contested human bodies around the cultural diversity of Indonesia. When Sukarno proclaimed the unity of the nationalist, religion, and communist (Nasakom), it was very difficult for many Indonesian people, because the slogan "persatuan poros Nasakom" (the unity in Nasakom) referred to leave behind the old habits, attitudes, and manners that have been around for a long time and are very diverse in the Indonesian archipelago.

Moreover, Sukarno's political affiliations have not only persuaded to reject the Western physical culture, but also another Indonesian cultural orientation, especially nonJavanese, which are suspected as having been affected by Western culture, with the reason that they were imperialist threats around Indonesia's territories. Sukarno has also proclaimed to resist against Indonesian who featured the modern body as they are equal to the antiGuided Democracy. In this period, Sukarno banned Star Weekly and other modernist newspapers, such as Pedoman, Keng Po, and Indonesia Raya. He has ignored the democratic ideas that people have the freedom to form their bodily orientations.

As a result, Sukarno's geopolitical motive has emerged antagonistic reactions from other Indonesian leaders, especially Mohamad Hatta (first Vice President of Indonesia). Hatta rejected Sukarno's geopolitical ideas about how the nation should be built based on territorial vision (Hatta, 1978). In contrast, Hatta suggested historical factors, not geopolitics, that had determined the Indonesian unity from Sumatra to Papua. The uniformity of suffering as a colonized nation was the main reason why several ethnicities in the archipelago allied with the Indonesia nation-state after 1945.

This political idea has threatened the national unity and has emerged strong antagonism between nationalist and modernist, between Javanese and non-Javanese. The contestation of the human body, which also means the contestation of national identity, has caused the national crisis of Indonesian unity. Sukarno and his political affiliations had a big problem, namely having no political will to accommodate the cultural heterogeneity in his political order. Guided bodies have threatened the commitment to diversity as represented in the slogan of Bhinneka Tunggal Ika (unity in the diversity). As a result, distrust has increased across the country and found the worst in the national crisis during the 1965s.

\section{CONCLUSION}

The idea of Indonesian bodies has been articulated and debated amongst generations, between the collective and sacred orientations of the traditional body with the new secular and individualized body. 
This paper has discussed the discursive practices of Indonesian media on the human body in the period of 1900-1965. It has also related the human body discourse with the contestation for Indonesian national identity. Applying discourse analysis as proposed by Norman Fairclough, the data were differentiated based on the historical power structures in the periods being studied, consisting of the Dutch colonial period (1990-1942), the Japanese occupation (1942-1945), and the independence period (1945-1965).

Before the Dutch occupation, the Javanese believes that the body is directly related to the sacred and supernatural powers. This idea was mainly represented in the Javanese rituals of "ritus kritis" (critical rites), which should be conducted to prepare human physic and spirit in the transitional processes within nature.

The Dutch occupation has transformed the main idea of the human body from the collective and sacred orientations to the new secular and individualized body. In this new perspective, every people have the choice to perceive his or her body as an independent self. The Dutch have to campaign public health, emphasizing physical hygiene, cleanliness, and modern bathing. They have also spread knowledge about body illness, skincare, scabies preventions, diseases, and other hygiene manner. During the 1920s, newspapers have become the main actor of this change, promoting pleasure, enjoyment, and other secular body images.

In contrast to the Dutch, Japanese occupation has stressed the total mobilization of the human body through military training, moral educations, and physical exercises. It is rooted in the ideology of Pan-Asianism, in which the 'Asia' was imagined as single and unity, beyond racial and cultural diversities in this region. The Japanese have provoked to accept collectivism ideas and to reject western individualism.

After independence, the human body discourse was more contested. It was closely related to the geopolitical circumstances, especially the strong tensions between nationalist (Javanese) and modernist (non-Javanese) discourses. On the one side, the nationalist suggested that Indonesia needs to form a collective physical identity for nation-building. In this sense, the Japanese body mobilizations have strongly influenced the nationalist ideas and practices of the human body. Moreover, in the end years of the Sukarno era, the body and its manners have become a very important field in the formation of national identity. On the other side, the modernist suggested accommodating cosmopolitanism, modernism, and individualism to build a national identity. Each party has its own affiliated media who campaigning their ideas on the human body.

The contestations between nationalist and modernist ideas have shown that the searching for Indonesian national identity was not complete until 1965, which has also triggered the crisis of national unity in the middle of the 1960s. At that moment, Indonesia needed more considerations to conceptualize the political policy that accommodates both nationalist and modernist parties.

\section{BIODATA}

Muhammad Ridhlo al Qodri Sri Utomo is a lecturer at Fakultas Tarbiyah dan Ilmu Keguruan, Institut Agama Islam Negeri (IAIN) Tulungagung, Indonesia. Email: ridhaalqadri@gmail.com / ridhaalqadri@iain-tulungagung.ac.id 


\section{REFERENCES}

Abdulgani, R. (1964). Pembinaan kesatuan bangsa. Jakarta: Departemen Penerangan RI.

Abdulgani, R. (1963). Pendjelasan Manipol dan Usdek. Jakarta: Pradnjaparamita.

Adams, C. (1966). Bung Karno: Penjambung lidah rakjat Indonesia. Jakarta: Gunung Agung.

Aidit, D. N. (2007). Which ideology is native? In H. Feith \& L. Castels (Eds.), Indonesian political thinking 1945-1965 (pp. 310-313). Singapore: Equinox.

Akashi, Y. (1993). Japanese cultural policy in Malay and Singapore, 1942-1945. In G. K. Goodman (Ed.), Japanese Cultural Policies in Southeast Asia During World War 2 (pp. 117-172). UK: Palgrave.

Atkinson, M. (2000). Norbert Elias and the body. In B. Turner (Ed.), Routledge handbook of body studies (pp. 49-61). London: Routledge.

Bahagia. (1929, 1 May). Ramboet netjis (advertisement). Semarang: Author.

Baserah, S. (1929, 5 January). Perempoean dan bobbed hair. Pertja Timoer (Vol. 2, No. 13). Medan: Drukkerij Pertja Timoer.

Buhger, D. H. (1983). Perubahan-perubahan struktur dalam masyarakat Jawa. Jakarta: Bharata.

Dwidjo. (1952, 26 January). Mode dan kesusilaan. Nasional (No. 4, Th. III). Jakarta: Badan Penerbitan Nasional.

Dwidjo. (1952, 29 March). Wanita dan rambut. Nasional (No. 13, Th. III). Jakarta: Badan Penerbitan Nasional.

Dwidjo. (1952, 20 September). Kesusilaan. Nasional (No. 38. Th. III). Jakarta: Badan Penerbitan Nasional.

Departemen Penerangan RI. (1965). Perintjian amanat 'tahun berdikari' 17 Agustus 1965. Jakarta: Author.

Dewantara, K. H. (1962). Karja: Bagian 1, pendidikan. Yogyakarta: Taman Siswa.

Djatikoesoemo, S. (1944, 27 June). Arti peradaban dan keboedajaan di dalam pembentoekan masjarakat baroe di Asia Timoer Raja. Borneo: Borneo Simboen.

Fairclough, N. (1993). Discourse and Social Change. Cambridge: Polity Press.

Feith, H., \& Castles, L. (Eds.) (2007). Indonesian political thinking 1945-1965. Jakarta: Equinox Publishing.

Feith, H. (2007). The decline of constitutional democracy. Singapore: Equinox.

Hatta, M. (1978). Pengertian pancasila. Jakarta: Idayu Press.

Hatta, M. (2007). Take the core of foreign culture and throw away the peel. In H. Feith \& L. Castels (Eds.), Indonesian political thinking 1945-1965 (pp. 286-291). Singapore: Equinox.

Hauw, O. (1949, 6 February). Moderne vrouven. Star Weekly (No. 162). Jakarta: N.V.Hd.MIJ. \& Drukkerij Keng Po.

Hotta, E. (2007). Pan-Asianism and Japan's war, 1931-1945. New York: Palgrave Macmillan.

Istidjab. (1931, 18 April). Bagaimanakah keadaan zenuwen toean? Bintang Timoer. Batavia: Bintang Timoer.

Joesoef, M. (1917). Kitab pemeliharaan diri. Betawi: Balai Pustaka.

Keizer, W. (1916). Pangreksaning awak: Lajang bab kawarasan kanggo pamoelangan Djawa. Rijswijk: Blankwaardt \& Schoonhoven.

Ken'ichi, G. (2007). Modern Japan and Indonesia: The dynamics and legacy of wartime rule. In P. Post \& E. Touwen-Bouwsma (Eds.), Japan, Indonesia, and the war. Leiden: KITLV Press. 
Koentjaraningrat. (1993). Masyarakat terasing di Indonesia. Jakarta: Gramedia Pustaka Utama.

Kumaratih. (1960). Pemeliharaan bagian-bagian tubuh jang kurang diperhatikan - Keluarga, No. 7. Jakarta: Jajasan Keluarga.

Kumaratih. (1962). Bagaimana merawat kulit kering - Keluarga, No. 8. Jakarta: Jajasan Keluarga.

Kumaratih. (1962). Home-wave: Untuk memiliki 3 model rambut - Keluarga, No. 2. Jakarta: Jajasan Keluarga.

Kumpulan Berita. (1965). BPS, aksi reaksi, Jakarta: P.T. Rakjat.

Kurasawa, A. (1989). Bangkitnya nasionalisme Indonesia: Budi Utomo, 1908-1918. Jakarta: Grafiti Press.

Kurasawa, A. (2015). Kuasa Jepang di Jawa: Perubahan sosial di pedesaan 1942-1945. Jakarta: Komunitas Bambu.

Lombard, D. (2008). Nusa Jawa: Silang budaya, Vol. 1: Batas-batas pembaratan. Jakarta: Gramedia.

Mangoensarkoro. (1943, 27 February). Zaman pendidikan sosial. Tjahaja.

McCormick, E. (1947, 5 January). Berbahajanya Koelit jang koerang terawat. Star Weekly (No. 53). Jakarta: N.V.Hd.MIJ. \& Drukkerij Keng Po.

McIntyre, A. (2005). Indonesian presidency: The shift from personal toward constitutional rule. USA: Rowman \& Littlefield.

Mrázek, R. (1997). Indonesian dandy: The politics of clothes in the late colonial period, 18931942. In H. S. Nordholt (Ed.), Outward appearances: Dressing state \& society in Indonesia (pp. 117-150). Netherlands: KITLV Press.

Mrázek, R. (2002). Engineers of happy land: Technology and nationalism in a colony. New Jersey: Princeton University.

Oetomo D. S. (1963). Tata krama nasional Indonesia: Etiquette, bagian 1. Yogyakarta: Ganefo.

Ooms, D. G. (1927). Bab badane Manoengsa: Lan bab Pangreksane (translated from Dutch to Javanese by K. H. Soebrata). Betawi: Balai Pustaka.

Pemandangan. (1938, 12 February). Obat kramas tjap dewa (advertisement). Jakarta: Author.

Pramono. (1964, 12 July). Penjebat pelanggaran kesoesilaan. Minggu Pagi (Vol. XVII, No. 15). Yogyakarta: Kedaulatan Rakjat.

Raffles, T. S. (2008). The history of Java (trans. E. Prasetyaningrum, N. Agustin \& I. Q. Mahbubah). Yogyakarta: Narasi.

Redaksi. (1926). Djalan boeat bersama-sama kerdja. Soeloeh Indonesia (No. 1, Vol. 10). Surabaya: Indonesische Studieclub.

Redaksi. (1947, 12 January). Roeangan wanita: Tentang dansa modern. Star Weekly (No. 54). Jakarta: N.V.Hd.MIJ. \& Drukkerij Keng Po.

Redaksi. (1955, 5 January). Anti-gaun you can see. Harian Rakjat. Jakarta: Penerbit Rakjat.

Redaksi. (1960). Bagaimana pinggangku menjadi ramping. Api Kartini (No. 4, Th. II). Jakarta: Jajasan Melati.

Redaksi. (1961). Mendjaga potongan tubuh. Keluarga (No. 3, Th. IX). Jakarta: Jajasan Keluarga.

Redaksi. (1962). Mode untuk hari-hari istimewa. Keluarga (No. 11-12). Jakarta: Jajasan Keluarga.

Redaksi. (1964, 12 August). Jogjakarta dalam sepekan: GOWJ ngganjang rambut sasak/rok span. Pesat (No. 31, Th. 20). Yogyakarta: Jajasan Penerbit Pesat.

Redaksi. (1964, 23 December). Dengan semangat tavip terus mengganjang kontra-revolusisubversi. Pesat (No, 50. Th. 20). Yogyakarta: Jajasan Penerbit Pesat. 
Redaksi. (1965). Paduan djas jang serasi. Keluarga (No. 3, Th. XIII). Jakarta: Jajasan Keluarga.

Redaksi (1965, 25 July). Sket masjarakat: Tata karma. Minggu Pagi (No. 7, Th. XVIII). Yogyakarta: Kedaulatan Rakjat.

Redaksi (1965, 26 September). Penderita tjatjat. Minggu Pagi (Vol. 13, No. 26). Yogyakarta: Kedaulatan Rakjat.

Ricklefs, M. C. A. (2001). History of modern Indonesia since c. 1200 (3rd Edition). Hampshire: Palgrave.

Satoshi, S. (2007). Synchronizing body states: training the body at school and performing the body in the city. In W. W. Kelly \& S. Atsuo (Eds.), This sporting life: Sport and body culture in modern Japan (pp. 55-66). Yale University Press.

Schurft. (1919). Penjakit koedis (in two Dutch and Malay languages). Batavia: Weltervreden.

Shilling, C. (2003). The body and social theory. London: Sage Publications.

Slamet, M. (2007). Let us not crawl back into our shells. In H. Feith \& L. Castels (Eds.), Indonesian political thinking 1945-1965 (pp. 300-306). Singapore: Equinox.

Soegiarti. (1936, 1 May). Mendidik ada mengandoeng matjam2 hal: Pidato dalam perajaan R. A. Kartini di Gedoeng Pergoeroean Ra'jat Kramat. Pemandangan. Jakarta: Pemandangan.

Soekarno. (1958). Pantja-sila sebagai dasar negara, III-IV: Kursus Presiden Soekarno tentang pantja-sila di Istana Negara, tanggal 5 Djuni 1958. Jakarta: Kementerian Penerangan RI.

Soekarno. (1959). Penemuan kembali revolusi kita: Pidato Presiden Republik Indonesia pada tanggal 17 Agustus 1959. Jakarta: Kementerian Penerangan RI.

Soekarno. (1961). Persatuan total dengan Poros Nasakom. Jakarta: Departemen Penerangan RI.

Soekarno. (1962). Tahun kemenangan. Jakarta: Kementerian Penerangan RI.

Soekarno. (1963). Genta suara revolusi. Jakarta: Departemen Penerangan RI.

Soekarno. (1963). Kembalilah mendjadi bangsa Samudera! Jakarta: Kementerian Penerangan RI.

Soekarno. (1964). Bertjita-tjitalah setinggi bintang dilangit: Amanat Presiden Soekarno pada peringatan Hari Pendidikan Nasional di Istana Olahraga Gelora Bung Karno, Senajan, Djakarta pada tanggal 2 Mei 1964. Jakarta: Departemen Penerangan RI.

Soekarno. (1968). Lahirnja pantjasila. Surabaya: PT. Grip.

Soekarno. (1986). Tahun tantangan. Amanat proklamasi, Vol. III: 1956-1960. Jakarta: Idayu Press.

Soekarno. (1986). Satu tahun ketentuan: Amanat Presiden Republik Indonesia pada ulang tahun proklamasi kemerdekaan Indonesia 17 Agustus 1957 di Jakarta. Amanat Proklamasi: Vol. III 1956-1960. Jakarta: Idayu Press.

Suryadarma, U. (2007). Fight cultural imperialism. In H. Feith \& L. Castels (Eds.), Indonesian political thinking 1945-1965 (pp. 306-310). Singapore: Equinox.

Taylor, J. G. (1997). Costume and gender in colonial Java, 1800-1940. In H. S. Nordholt (Ed.), Outward appearances: Dressing state \& society in Indonesia (pp. 85-116). Netherlands: KITLV Press.

Taylor, J. G. (2011). Bathing and hygiene: Histories from the KITLV images archive. In K. van Dijk (Ed.), Cleanliness and culture: Indonesian histories (pp. 41-42). Leiden: KITLV Press.

Tim Penyusun. (1951, 15 February). Madjalah rakjat (Th. 2, No. 2). Jakarta: Djawatan Pendidikan Masjarakat. 
Tim Penyusun. (1964). Pembinaan mental dan kesatuan bangsa. Jakarta: Lembaga Pembinaan Kesatuan Bangsa.

Turner, B. (2007). The body and society (3rd ed.). London: Sage Publications.

Wiedija H. S. (1955, 5 February) Menjongsong diskusi besar masalah demoralisasi di kalangan peladjar. Harian Rakjat. Jakarta: Penerbit Rakjat.

Zinoman, P. (2014). Colonizing minds and bodies: Schooling in colonial Southeast Asia. Routledge handbook of Southeast Asia history (pp. 46-54). New York: Routledge. 